\title{
The importance of lung function, non-malignant diseases associated with asbestos, and symptoms as predictors of ischaemic heart disease in shipyard workers exposed to asbestos
}

\author{
Åke Sandén, Bengt Järvholm, Sven Larsson
}

\begin{abstract}
The mortality from ischaemic heart disease was studied in a prospective cohort of 1725 shipyard workers exposed to asbestos. The analyses were stratified for age and smoking habits and restricted to men. In agreement with other findings, men with impaired lung function had a significantly higher risk (relative risk $(R R)=3.5$ ) of dying from ischaemic heart disease than men with normal lung function. Men with asbestosis or suspected asbestosis had a significantly higher risk $(R R=3 \cdot 1)$ of dying from ischaemic heart disease than men without asbestosis. Thus asbestosis or suspected asbestosis also seemed to be a risk factor for ischaemic heart disease. This finding was independent of respiratory function. There was no increased risk for ischaemic heart disease in men with compared with men without pleural plaques. Men with production of phlegm or sputum and wheezing or whistling had no increased risk for ischaemic heart disease compared with men without these symptoms. In the group with normal lung function men with dyspnoea had a significantly higher risk of dying from ischaemic heart disease than men without dyspnoea. The findings for men with asbestosis or suspected asbestosis indicated a further risk factor besides impaired lung function, in persons exposed to asbestos. Perhaps this risk factor is due to lesions of the pericardium with consequences for heart function.
\end{abstract}

(British fournal of Industrial Medicine 1993;50:785-790)

Department of Occupational Medicine, Sahlgrenska Hospital, S:t Sigfridsgatan 85, S-41266 Göteborg, Sweden

A Sandén, B Järvholm

Department of Pulmonary Medicine, University of Gothenburg, Renströmska sjukhuset, Box 17301, S-40266 Göteborg; Sweden

S Larsson
Several studies have shown that impaired lung function is a predictor of increased mortality from ischaemic heart disease. ${ }^{1-5}$ In these studies lung function was measured by forced expiratory volume in one second $\left(F E V_{1}\right), 5$ forced vital capacity (FVC), ${ }^{13}$ and peak expiratory flow. ${ }^{4}$ Multivariate analysis $^{1}{ }^{3}$ showed that impaired lung function remained a strong predictor of increased mortality from cardiovascular disease even when other major cardiovascular risk factors were taken into account. The explanation for the association between impaired lung function and morbidity or mortality from ischaemic heart disease is speculative and a number of mechanisms have been proposed. ${ }^{1-4}$ One possibility is that impaired lung function might reflect impaired cardiac function. Another is that smoking may lead to both lung impairment and increased incidence of ischaemic heart disease. A third is that hypoxic effects promote myocardial ischaemia.

Exposure to asbestos may impair lung function and asbestos related diseases such as asbestosis ${ }^{6} 7$ and pleural diseases ${ }^{89}$ are associated with impaired lung function. These facts, together with the knowledge that impaired lung function predicts a risk of mortality from ischaemic heart disease made it interesting to investigate this risk in a group of shipyard workers exposed to asbestos who had a high prevalence of asbestosis and pleural plaques. Previous studies of workers exposed to asbestos have not indicated an increased risk of ischaemic heart disease, ${ }^{10-15}$ but these studies have compared mortality in workers with that in the general population, which could lead to a bias through the so called healthy worker effect. In our study, therefore, we compared the mortality from ischaemic heart disease in workers exposed to asbestos with and without impaired lung function, asbestos related diseases, and respiratory symptoms. The objective was to determine if the earlier mentioned association between ischaemic heart disease and lung function also occurred among persons exposed to a dust known to impair lung function and if the mentioned diseases or symptoms predicted an 
Table 1 Age, smoking habits, and mortality from ischaemic heart disease

\begin{tabular}{|c|c|c|c|c|}
\hline \multirow[b]{3}{*}{ Smoking habits } & \multicolumn{4}{|c|}{ Year of birth } \\
\hline & \multicolumn{2}{|l|}{$1910-9$} & \multicolumn{2}{|l|}{$1920-9$. } \\
\hline & $\begin{array}{l}\text { Total } \\
\text { No (\%) }\end{array}$ & $\begin{array}{l}I H D^{*} \\
\text { No (\%) }\end{array}$ & $\begin{array}{l}\text { Total } \\
\text { No (\%) }\end{array}$ & $\begin{array}{l}I H D^{*} \\
\text { No (\%) }\end{array}$ \\
\hline $\begin{array}{l}\text { Non-smokers } \\
\text { Ex-smokers } \\
\text { Smokers }\end{array}$ & $\begin{array}{l}109(17) \\
275(43) \\
243(38)\end{array}$ & $\begin{array}{r}3(3) \\
16(6) \\
21(9)\end{array}$ & $\begin{array}{l}217(20) \\
379(35) \\
480(44)\end{array}$ & $\begin{array}{r}3(1) \\
17(4) \\
20(4)\end{array}$ \\
\hline
\end{tabular}

${ }^{\star}$ Men who died from ischaemic heart disease (IHD) (\% of each group)

increased risk of mortality from ischaemic heart disease.

\section{Subjects}

A total of 3899 shipyard workers, earlier exposed to asbestos, participated in a health monitoring programme between 1977 and 1979. Exposure to asbestos stopped at the shipyards in 1972. After that time only a few men who pulled down asbestos in ships at a repair yard were exposed. Participation in the programme was free and voluntary. Strong support from the union to have all their members who were exposed to asbestos examined contributed to a participation estimated to be more than $90 \%$ of workers earlier exposed to asbestos.

As death due to ischaemic heart disease is rare in young persons, this study was restricted to all men born between 1910 and $1929(n=1725)$ (table 1$)$. Women were excluded as there were few $(n=6)$.

\section{Methods}

This was a prospective cohort study in which the mortality from ischaemic heart disease (International Classification of Diseases-8 (ICD-8) 410-414) was compared in men with impaired lung function and men with normal lung function. The mortality from ischaemic heart disease was also compared in men with and without asbestosis or suspected asbestosis, in men with and without pleural plaques, and in men with and without some symptoms. The determinants were diagnosed at a health check up between 1977 and 1979.

The observation period for each man was the time between the health check up and 31 December 1988 or the point of death or emigration if this occurred before the end point. Three men emigrated, which was the only loss during the follow up period.

The cases of ischaemic heart disease were found by linking the national identity number of each man with the Swedish Death Register. The underlying cause of death was used. The relative risk was estimated as the incidence ratio of mortality from ischaemic heart disease in men with the present determinants to men without these determinants.

The health monitoring programme included a self administered questionnaire containing questions about smoking habits, exposure to asbestos, and some symptoms. The questions about symptoms were: (1) Do you usually cough up anything from your chest (phlegm or sputum) in the morning in winter? (2) Do you cough up anything from your chest during the day or night in winter? (3) Do you cough up anything from your chest for three months of the year? (4) Does your chest wheeze or whistle most days or nights? (5) Does your chest wheeze or whistle when you have a cold? (6) Does your chest wheeze or whistle even when you do not have a cold? (7) Are you troubled by shortness of breath when hurrying on level ground or walking up a slight hill? (8) Are you more troubled by shortness of breath than other people of your age when walking together on level ground? (9) Do you ever have to stop for breath when walking at your own pace on level ground?

Each man had a spirometric examination. The spirometry was carried out by trained nurses, with a calibrated dry bell spirometer (vitalograph). Three acceptable recordings were made and the highest values were used. The $\mathrm{FEV}_{1}$ and FVC were expressed as $\%$ of the predicted value with reference values established by Berglund et al. ${ }^{16}$ Impaired lung function was defined as $\mathrm{FEV}_{1}$ or FVC less than $80 \%$ of the predicted value. Normal lung function was here defined as both $\mathrm{FEV}_{1}$ and FVC $90 \%$ of the predicted value or higher.

Each man also had a chest $x$ ray film taken (posteroanterior and lateral views). The chest films were read by trained physicians at a Department of Pulmonary Medicine. Pleural plaques were classified according to Thiringer et al. ${ }^{17}$ Briefly, the definition requires circumscribed lesions at least $5 \mathrm{~mm}$ thick, if not calcified, and on the diaphragm at least $3 \mathrm{~mm}$ thick, if not calcified. Men in whom $x$ ray films or lung function tests indicated asbestosis were investigated at the lung clinic. Patients were considered to have asbestosis or suspected asbestosis if the chest radiographs were compatible with basal lung fibrosis and lung function indicated lung fibrosis or a lung biopsy showed asbestosis.

The subjects were stratified age classes (10 years) and smoking habits. The Mantel-Haenszel method, ${ }^{18}$ as modified by Rothman and Boice, ${ }^{19}$ was used in the stratified analyses. The $95 \%$ confidence interval $(95 \% \mathrm{CI})$ was calculated according to a method proposed by Miettinen. ${ }^{20}$

\section{Results}

The only loss during the follow up was due to emigration $(n=3)$. These men were included in the 
Table 2 Lung function and ischaemic heart disease mortality

\begin{tabular}{|c|c|c|c|c|}
\hline \multirow[b]{2}{*}{$\%$ Of predicted value } & \multicolumn{2}{|l|}{$F E V_{1}$} & \multicolumn{2}{|l|}{ FVC } \\
\hline & $\mathrm{No}^{*}$ & $I H D+$ & $\mathrm{No}^{*}$ & $I H D+$ \\
\hline $\begin{array}{l}\text { Less than } 80 \% \\
80 \% \text { to } 89 \% \\
90 \% \text { or higher } \\
\text { Unknown } \neq \\
\text { Total }\end{array}$ & $\begin{array}{l}187 \\
198 \\
1254 \\
86 \\
1725\end{array}$ & $\begin{array}{l}20 \\
17 \\
41 \\
2 \\
80\end{array}$ & $\begin{array}{l}290 \\
328 \\
1015 \\
92 \\
1725\end{array}$ & $\begin{array}{l}30 \\
16 \\
32 \\
2 \\
80\end{array}$ \\
\hline
\end{tabular}

*Total number of persons at the health check up.

tNumber of deaths from ischaemic heart disease (IHD) during the follow up.

‡Unknown because of incomplete information.

study until the moment of emigration. Two hundred and thirty three men died during the follow up period. There were 80 deaths from ischaemic heart disease, among whom $7 \cdot 5 \%$ were non-smokers, $41 \cdot 3 \%$ were ex-smokers, and $51 \cdot 2 \%$ were current smokers (table 1).

At the health check up, the prevalence of pleural plaques was 0.41 and of asbestosis or suspected asbestosis 0.03 . There were eight deaths from ischaemic heart disease in men with asbestosis or suspected asbestosis and 39 deaths from ischaemic heart disease in men with pleural plaques during the follow up period.

An $\mathrm{FEV}_{1}$ less than $80 \%$ of the predicted value was found in 187 men and FVC was less than $80 \%$ of the predicted value in 290 men (table 2).

\section{IMPAIRED LUNG FUNCTION AND DEATH FROM ISCHAEMIC HEART DISEASE}

Men with impaired lung function had a significantly higher risk of dying from ischaemic heart disease than men with normal lung function (table 3 ). The relative risk (RR) was 3.5 (95\% CI 2.2-5.7). A similar analysis of mortality from all causes excluding death from ischaemic heart disease showed an $R R$ of $1.5(95 \%$ CI $1 \cdot 0-2 \cdot 1)$. All men in the two lung function strata in this study who died of ischaemic heart disease during the followup period had estimated their exposure to asbestos as low or very low

Table 3 Mortality from ischaemic heart disease (per 1000 person-years) in men with impaired and normal lung function

\begin{tabular}{llll}
\hline & \multicolumn{3}{l}{ Mortality ( $\left.\times 10^{3}\right)$} \\
\cline { 2 - 4 } $\begin{array}{l}\text { Smoking habits at } \\
\text { health check up }\end{array}$ & $\begin{array}{l}\text { Year of } \\
\text { birth }\end{array}$ & $\begin{array}{l}\text { Impaired } \\
\text { lung function * }\end{array}$ & $\begin{array}{l}\text { Normal } \\
\text { lung functiont }\end{array}$ \\
\hline Non-smokers: & $1910-9$ & $7 \cdot 3(1)$ & $2.8(2)$ \\
& $1920-9$ & $9 \cdot 7(2)$ & $1.0(1)$ \\
Ex-smokers: & $1910-9$ & $7 \cdot 5(5)$ & $3.9(5)$ \\
& $1920-9$ & $5.1(3)$ & $5.3(13)$ \\
Current smokers: & $1910-9$ & $20.5(13)$ & $2.9(3)$ \\
& $1920-9$ & $14.1(12)$ & $2.2(6)$ \\
\hline
\end{tabular}

${ }^{\star} \mathrm{FEV}_{1}$ or FVC less than $80 \%$ of predicted value.

$+\mathrm{FEV}_{1}$ and FVC of $90 \%$ of predicted value or higher.

Number of cases in parentheses.
Table 4 Mortality from ischaemic heart disease (per 1000 person-years) in men with and without asbestosis or suspected asbestosis

\begin{tabular}{llll}
\hline & \multicolumn{3}{l}{ Mortality $\left(\times 10^{3}\right)$} \\
\cline { 2 - 4 } $\begin{array}{l}\text { Smoking habits at } \\
\text { health check up }\end{array}$ & $\begin{array}{l}\text { Year of } \\
\text { birth }\end{array}$ & $\begin{array}{l}\text { With asbestosis } \\
\text { or suspected } \\
\text { asbestosis }\end{array}$ & $\begin{array}{l}\text { Without asbestosis } \\
\text { or suspected } \\
\text { asbestosis }\end{array}$ \\
\hline Non-smokers & $1910-9$ & 0 & $2 \cdot 8(3)$ \\
Ex-smokers & $1920-9$ & 0 & $1 \cdot 4(3)$ \\
Current smokers & $1910-9$ & $11 \cdot 0(1)$ & $5 \cdot 8(15)$ \\
& $1920-9$ & $7 \cdot 7(1)$ & $4 \cdot 3(16)$ \\
& $1910-9$ & $39 \cdot 8(6)$ & $7 \cdot 2(15)$ \\
& $1920-9$ & 0 & $4 \cdot 3(20)$ \\
\hline
\end{tabular}

Number of cases in parentheses.

at the health check up. An analysis of the risk of dying from ischaemic heart disease in men with FEV $_{1}$ or FVC between 60 and $79 \%$ of the predicted value compared with men with normal lung function showed an RR of 3.6 (95\% CI 2.2-5.8).

There were only five deaths from non-malignant respiratory diseases (ICD-8 490-493). Three of these were men who were ex-smokers with impaired lung function at the health check up. Two were current smokers with normal lung function.

\section{ASBESTOSIS AND DEATH FROM ISCHAEMIC HEART} DISEASE

The $R R$ of mortality from ischaemic heart disease in men with asbestosis or suspected asbestosis was $3 \cdot 1$ (95\% CI 1.5-6.4) compared with men without asbestosis (table 4) after stratification for age and smoking habits. Thus asbestosis or suspected asbestosis seemed to be a risk factor for mortality from ischaemic heart disease. This was apparently independent of respiratory function because a similar analysis restricted to men with $\mathrm{FEV}_{1}$ or FVC less than $80 \%$ of the predicted value showed an $R R$ of $3 \cdot 1(95 \%$ CI 1.0-9.1).

Seven of the eight cases who died from ischaemic heart disease in men with asbestosis or suspected asbestosis were ex-smokers or current smokers in the older group. An analysis restricted to this group, that is, ex-smokers and current smokers born between 1910 and 1919, showed an RR of mortality from ischaemic heart disease in men with asbestosis or suspected asbestosis of 4.3 (95\% CI 2.0-9.3) compared with men without asbestosis (table 4) stratifying for smoking habits. A similar analysis but restricted to men with FEV1 or FVC less than $80 \%$ of the predicted value showed an $R R$ of 3.5 (95\% CI 1.3-9.3).

\section{PLEURAL PLAQUES AND DEATH FROM ISCHAEMIC HEART DISEASE}

The $R R$ of mortality from ischaemic heart disease in men with pleural plaques compared with men without pleural plaques was $1.3(95 \% \mathrm{CI} 0 \cdot 8-2 \cdot 0)$ after stratification for age and smoking habits. In a 
Table 5 Relative risk of mortality from ischaemic heart disease in men with compared with men without symptoms

\begin{tabular}{|c|c|c|}
\hline \multirow[b]{2}{*}{$\begin{array}{l}\text { Symptoms } \\
\text { (no of questions)* }\end{array}$} & \multicolumn{2}{|l|}{$R R$} \\
\hline & $\begin{array}{l}\text { Men with impaired } \\
\text { lung function } \neq \\
R R \dagger(95 \% \text { CI })\end{array}$ & $\begin{array}{l}\text { Men with normal } \\
\text { lung function } \$ \\
R R+(95 \% \mathrm{CI})\end{array}$ \\
\hline $\begin{array}{l}\text { Phlegm or sputum } \\
(1,2, \text { or } 3)\end{array}$ & $0.76(0.51-1.1)$ & $0.92(0.42-2.0)$ \\
\hline $\begin{array}{l}\text { Wheezing or whistling } \\
(4,5, \text { or } 6)\end{array}$ & $1 \cdot 3(0 \cdot 52-3 \cdot 1)$ & $1 \cdot 3(0.53-3 \cdot 1)$ \\
\hline $\begin{array}{l}\text { Dyspnoea, slight (7) } \\
\text { Dyspnoea, moderate (8) } \\
\text { Dyspnoea, serious (9) }\end{array}$ & $\begin{array}{l}1.2(0.59-2.4) \\
1.0(0 \cdot 40-2 \cdot 7) \\
1.9(0 \cdot 72-5 \cdot 0)\end{array}$ & $\begin{array}{l}3 \cdot 0(1 \cdot 4-6 \cdot 2) \\
4 \cdot 1(1 \cdot 4-12 \cdot 2) \\
11 \cdot 4(5 \cdot 2-25 \cdot 3)\end{array}$ \\
\hline
\end{tabular}

${ }^{\star}$ For details of the questions see text (methods).

Incidence density ratio adjusted for year of birth and smoking habits (Mantel-Haenszel estimate)

$\ddagger$ Men with FEV1 or FVC less than $80 \%$ of predicted value.

SMen with FEV1 and FVC $\mathbf{9 0 \%}$ of predicted value or higher.

similar analysis restricted to men with impaired lung function the RR was $0.94(95 \% \mathrm{CI} 0 \cdot 8-1 \cdot 2)$.

\section{RESPIRATORY SYMPTOMS AND DEATH FROM}

ISCHAEMIC HEART DISEASE

Analyses of the RR for men with symptoms compared with men without symptoms showed no increased risk in men with production of phlegm or sputum and wheezing or whistling. Among men with dyspnoea, there was no increased risk in those with impaired lung function but an increased risk was found in those with normal lung function (table 5).

\section{Discussion}

This study confirmed the findings that impaired lung function predicts an increased risk of mortality from ischaemic heart disease. Marcus et $a l^{5}$ explained this by cigarette smoking, which leads to both impaired lung function and a higher incidence of ischaemic heart disease, but other investigators were of the opinion that the relation to subsequent coronary events is not well explained and that the risk was independent of the cause of the impairment of lung function. ${ }^{1-3}$ One cause of impaired lung function may be exposure to asbestos ${ }^{6-9}$ and if some of the impairment found in our study was caused by this, the exposure may have contributed to cases of death from ischaemic heart disease.

There are other major cardiovascular risk factors. Kannel $e t a b^{3}$ showed that vital capacity is a predictor of ischaemic heart disease events in a multivariate analysis taking into account all major cardiovacular risk factors including age, obesity, blood pressure, cigarette smoking, heart rate, and cholesterol and glucose concentrations. Friedman et $a^{1}{ }^{1}$ found similar results in a multiple regression analysis taking into account systolic blood pressure, cholesterol concentrations, and cigarette smoking.
Thus impaired lung function seemed to rank high as a predictor among the major risk factors for mortality from ischaemic heart disease. ${ }^{3}$ In our present study, we have chosen to investigate the effects of determinants that may be associated with lung function and also to investigate whether the occurrence of diseases induced by asbestos, such as asbestosis and pleural plaques was associated with an excess risk of ischaemic heart disease.

\section{VALIDITY}

The exposure to asbestos stopped in 1972 for these men. A high prevalence of pleural plaque and asbestosis or suspected asbestosis in the group as well as a high incidence of mesothelioma ${ }^{21}$ confirmed that they had had considerable earlier exposure to asbestos.

A comparison of risks of mortality in workers with that in the general population usually shows a lower risk in workers (healthy worker effect). To avoid such a bias, we compared mortality from ischaemic heart disease in workers with and without the student determinants in the same cohort.

If there were less than perfect measurements at the health check up, there could have been misclassifications of determinants, causing random errors and an underestimated risk. To minimise these errors, the spirometry was done with calibrated apparatus and by trained nurses and the chest $x$ ray films were read by a small group of trained physicians.

The loss to follow up was small $(n=3)$ and cannot have influenced the results.

Sex, age, and smoking habits are possible confounders when investigating the risk of mortality from ischaemic heart disease and these were considered through restriction and stratification. The other major cardiovascular risk factors cannot be excluded as confounders but it seems unlikely that strong correlations would exist between lung function and hypertension, cholesterol concentrations, or occurrence of diabetes mellitus in these men.

\section{IMPAIRED LUNG FUNCTION}

Our study indicated that the impairment of lung function in shipyard workers was high enough to predict a risk of mortality from ischaemic heart disease although it was moderate enough to allow work in the physically demanding shipyard industry. Ten per cent of men with impaired lung function died of ischaemic heart disease during the follow up, compared with $3 \%$ of men with normal lung function. This indicated that impaired lung function was a strong predictor of mortality from ischaemic heart disease in this study. The finding may be compared with that for smoking. About $6 \%$ of smokers and $1.8 \%$ of non-smokers died of ischaemic heart disease. 
Friedman $e t$ al found an increased $R R$ of myocardial infarction as the ratio actual: expected VC diminished. They divided the ratios in quartiles. With a risk of 1.0 assigned to the highest quartile an $R R$ of 2.3 was found in the lowest quartile. The RR of mortality from ischaemic heart disease was 3.5 in our study comparing workers with and without impaired lung function. Beaty et al found an RR for all causes of death of 1.81 when impaired and non-impaired subjects were compared. A similar analysis in the present study showed an RR of 2.0 for all causes and 1.5 for all causes excluding death from ischaemic heart disease. Thus in these comparisons the risk seemed to be high in impaired persons among shipyard workers. One cause may be that shipyard workers had more impaired lung function than subjects in the other studies although most shipyard workers had a moderate impairment of between $60 \%$ and $79 \%$ of the predicted value for FEV1 or FVC. Few men had values below $60 \%$.

\section{ASBESTOSIS OR SUSPECTED ASBESTOSIS}

There were few men $(n=52)$ in the study with asbestosis or suspected asbestosis and the cases of mortality from ischaemic heart disease in these men were concentrated among ex-smokers and current smokers in the older group. In older ex-smokers and smokers, the RR of mortality from ischaemic heart disease was $4 \cdot 3(95 \% \mathrm{CI} 2 \cdot 0-9 \cdot 3)$ in men with asbestosis or suspected asbestosis compared with men without asbestosis but the $R R$ was 3.9 (95\% CI $1 \cdot 8-8 \cdot 6)$ in men with impaired lung function compared with men with normal lung function. In older ex-smokers and current smokers with impaired lung function, the mortality from ischaemic heart disease was $42.3 \quad(95 \% \quad C I$ 13.7-98.7) per 1000 person-years in men with asbestosis or suspected asbestosis but $11.0(95 \% \mathrm{CI}$ 5.9-18.8) in men without asbestosis or suspected asbestosis. Thus the mortality from ischaemic heart disease was 3.8 times higher in men with asbestosis.

In older smokers the mortality from ischaemic heart disease was 39.8 (95\% CI 14.6-86.6) per 1000 person-years in men with asbestosis or suspected asbestosis but $7 \cdot 2(95 \%$ CI $4 \cdot 0-11 \cdot 8)$ in men without the disease. Thus for these groups the mortality from ischaemic heart disease was 5.5 times higher in men with asbestosis or suspected asbestosis.

These findings indicate that the occurrence of asbestosis increases the risk of mortality from ischaemic heart disease. Asbestosis is associated with fibrotic reactions in the lungs, with increased stiffness of the tissue, but small airways disease is also found in persons exposed to asbestos. ${ }^{22}$ Perhaps these pathological changes contribute to an excess risk of ischaemic heart disease through episodes of hypoxaemia.

There is also evidence that asbestos fibres can reach the pericardium. A few cases of malignant mesothelioma in the pericardium have been found. ${ }^{23} 24$ Other evidence is that there are reported cases of pericardial effusion and constrictive pericarditis induced by asbestosis. ${ }^{25} 26$ In some of these cases non-specific fibrous thickening of the pericardium was shown. ${ }^{25}$ It is therefore possible that the excess risk of ischaemic heart disease in persons exposed to asbestos is not only an effect of impaired lung function but also of lesions of the pericardium with functional consequences for the heart.

Although several studies of workers exposed to asbestos have not found an increased risk of cardiovascular mortality ${ }^{10-15}$ there are some studies where an increased risk was found. 62728 These studies were not focused on this problem but it should be noted that in those with an increased risk of cardiovascular mortality there was a high mortality due to asbestosis.

\section{PLEURAL PLAQUES}

We found no increase of mortality from ischaemic heart disease in men with pleural plaques. Although impairment of lung function has been found in men with pleural plaques, ${ }^{8}$ the impairment was moderate and men with pleural plaques had in general $5 \%$ lower FVC than controls. ${ }^{9}$ This impairment is probably too small to contribute to an excess risk of ischaemic heart disease.

\section{SYMPTOMS}

A study by Friedman et al ${ }^{1}$ indicated that dyspnoea was related to impaired vital capacity as well as cough and sputum production. Järvholm and Larsson $^{29}$ found a correlation between reported dyspnoea and lung function. Dyspnoea may reflect either heart or lung disease. Cough, sputum production, and wheezing or whistling may be more closely associated with obstructive lung disease. ${ }^{1}$

In the present study, there was no increased risk of ischaemic heart disease in men with production of phlegm or sputum and wheezing or whistling compared with men without these symptoms. These symptoms therefore seemed to be of low value as predictors of risk of mortality from ischaemic heart disease. In men with normal lung function, dyspnoea was a strong predictor of death from ischaemic heart disease. Cardiac impairment was a more probable cause of the dyspnoea in these men and questions about dyspnoea thus seemed to be important in this respect. It is difficult to explain why dyspnoea was not a predictor in men with impaired lung function, but the confidence intervals are wide. 


\section{Conclusions}

This study confirmed other findings that impaired lung function predicts a risk of mortality from ischaemic heart disease. There are several possible causes of the impairment and among these are harmful exposure in the environment or workplace such as exposure to asbestos. The finding that asbestosis further increased the risk of mortality from ischaemic heart disease indicated a further risk effect besides impaired lung function in persons exposed to asbestos. Perhaps this additional risk factor results from lesions of the pericardium with functional consequences for the heart. To further investigate this it is desirable that the question is considered both in studies of mortality in cohorts exposed to asbestos and by pathologists at necropsy of cases exposed to asbestos.

This work was supported by the Swedish Work Environment Fund.

Requests for reprints to: Åke Sandén, Department of Occupational Medicine, S:t Sigfridsgatan 85, S-41266 Göteborg, Sweden.

1 Friedman GD, Klatsky AL, Siegelaub AB. Lung function and risk of myocardial infarction and sudden cardiac death. $N$ Engl f Med 1976;294:1071-5.

2 Beaty TH, Cohen BH, Newill CA, Menkes HA, Diamond EL,Chen CJ. Impaired pulmonary function as a risk factor for mortality. Am $\mathcal{F}$ Epidemiol 1982;116:102-13.

3 Kannel WB, Hubert H, Lew EA. Vital capacity as a predictor of cardiovascular disease: The Framingham Study. Am Heart $\mathcal{F} 1983 ; 105: 311-5$.

4 Persson C, Bengtsson, C, Lapidus L, Rybo E, Thiringer G, Wedel $\mathrm{H}$. Peak expiratory flow and risk of cardiovascular disease and death. Am $\Im$ Epidemiol 1986;124:942-8.

5 Marcus BE, Curb JD, MacLean CJ, Reed DM, Yano K. Pulmonary function as a predictor of coronary heart disease. Am F Epidemiol 1989;129:97-104.

6 Enterline PE, Hartley J, Henderson V. Asbestos and cancer: a cohort followed up to death. $\mathrm{Br} \mathcal{F}$ Ind Med 1987;44: 396-401.

7 Bégin R, Cantin A, Berthiaume Y, Boileau R, Péloquin S, Massé S. Airway Function in Lifetime-Nonsmoking Older Asbestos Workers. Am $\Im$ Med 1983;75:631-8.

8 Kouris SP, Parker DL, Bender AP, Williams AN. Effects of asbestos-related pleural disease on pulmonary function. Scand I Work Environ Health 1991;17:179-83.

9 Järvholm B, Sandén $\AA$. Pleural plaques and respiratory function. Am F Ind Med 1986;10:419-26
10 Puntoni R, Vercelli M, Merlo F, Valerio F, Santi L. Mortality among shipyard workers in Genoa, Italy. Am NY Acad Sci 1979;330:353-77.

11 Beaumont J, Weiss N. Mortality of welders shipfitters, and other metal trades workers in boiler-makers local No.104, AFL-C10. Am f Epidemiol 1980;112:775-86.

12 Hughes Jm, Weill H, Hammad Y. Mortality of workers employed in two asbestos cement manufacturing plants. Brf Ind Med 1987;44:161-74.

13 Albin M, Jakobsson $K$, Attewell $R$, Johansson $L$, Welinder $H$. Mortality and cancer morbidity in cohorts of asbestos cement workers and referents. Br $\mathcal{F}$ Ind Med 1990;47: 602-10.

14 Piolatto G, Negri E, La Vecchia C, Pira E, Decarli A, Peto J. An update of cancer mortality among chrysotile asbestos miners in Balangero, northern Italy. $\mathrm{Br} F$ Ind Med 1990; 47:810-4

15 Simonato L, Fletcher A C, Andersen A, et al. A historical prospective study of European stainless steel, mild steel, and shipyard welders. Br F Ind Med 1991;48:145-54.

16 Berglund E, Birath G, Bjure J, et al. Spirometric studies in normal subjects. Acta Med Scand 1963;173:185-92.

17 Thiringer, G, Blomkvist N, Brolin I, Mattsson S-B. Pleural plaques in chest X-rays of lung cancer patients and matched controls. (Preliminary results). Eur $\mathcal{F}$ Respir Dis 1980; 61(suppl 107):119-23.

18 Mantel N, Haenszel W. Statistical aspects of the analysis of data from retrospective studies of disease. $\mathcal{F}$ Natl Cancer Inst 1959;22:719-49.

19 Rothman KJ, Boice JD. Epidemiologic analysis with a programmable calculator. Boston, MA: Epidemiology resources Inc, 1982.

20 Miettinen OS. Estimability and estimation in case-referent studies. Am $\mathcal{F}$ Epidemiol 1976;103:226-35.

21 Sandén A, Järvholm B. A study of possible predictors of mesothelioma in shipyard workers exposed to asbestos. $\mathcal{f}$ Occup Med 1991;33:770-3.

22 Churg A. Current issues in the pathologic and mineralogic diagnosis of asbestos-induced disease. Chest 1983;3:275-80.

23 Enterline PE, Henderson VL. Geographic patterns for pleural mesothelioma deaths in the United States, 1968-81. F Natl Cancer Inst 1987;79:31-7.

24 Turk J, Kenda M, Kranjec I. Primary malignant pericardial mesothelioma. Klin Wochenschr 1991;69:674-8.

25 Davies D, Andrews MI, Jones JS. Asbestos induced pericardial effusion and constrictive pericarditis. Thorax 1991;46: 429-32.

26 Fischbein L Namade M, Sachs RN, Robineau M, Lanfranchi J. Chronic constrictive pericarditis associated with asbestosis. Chest 1988;94:646-7.

27 Dement JM, Harris RL, Symons MI, Shy CM. Exposures and mortality among chrysotile asbestos workers. Part II:mortality. Am f Ind Med 1983;4:421-33.

28 Peto J, Doll R, Hermon C, Binns W, Clayton R, Goffe T. Relationship of mortality to measures of environmental asbestos pollution in an asbestos textile factory. Ann Occup Hyg 1985;29:305-55.

29 Järvholm B, Larsson S. Do pleural plaques produce symptoms? A brief report. f Occup Med 1988;30:345-7.

Accepted 19 October 1992 